\title{
Production of superoxide anion and hydrogen peroxide associated with cell growth of Chattonella antiqua
}

\author{
Daekyung Kim ${ }^{1,2}$, Masataka Watanabe ${ }^{1, *}$, Yoko Nakayasu' ${ }^{1}$, Kunio Kohata ${ }^{3}$ \\ ${ }^{1}$ Water and Soil Environment Division, National Institute for Environmental Studies, Onogawa, Tsukuba, Ibaraki 305-8506, Japan \\ ${ }^{2}$ Japan Society for the Promotion of Science (JSPS), Kojimachi Office, Yamato Building, 5-3-1 Kojimachi, Chiyoda-ku, \\ Tokyo 102-8471, Japan \\ ${ }^{3}$ Watershed Environmental Management Group, National Institute for Environmental Studies, Onogawa, Tsukuba, \\ Ibaraki 305-8506, Japan
}

\begin{abstract}
The production of reactive oxygen species (ROS) by the red tide flagellate Chattonella antiqua (Raphidophyceae) was investigated. Flagellates were grown in an NIES (National Institute for Environmental Studies) culture tank containing $1 \mathrm{~m}^{3}$ of $\mathrm{f} / 2$ medium under synchronized light conditions (12:12 h, L:D period). Raphidophycean flagellates are known to form ROS, such as the superoxide anion $\left(\mathrm{O}_{2}^{-}\right)$and hydrogen peroxide $\left(\mathrm{H}_{2} \mathrm{O}_{2}\right)$ under normal growth conditions. We confirmed that $C$. antiqua generated $\mathrm{O}_{2}^{-}$depending on the cell growth phase by chemiluminescence responses. $\mathrm{O}_{2}^{-}$production had a maximum value during the exponential growth phase and subsequently decreased in the stationary phase. However, the maximum production of $\mathrm{H}_{2} \mathrm{O}_{2}$ occurred in the early stationary growth phase. These results showed that $\mathrm{O}_{2}^{-}$and $\mathrm{H}_{2} \mathrm{O}_{2}$ generation pathways were different from each other in $C$. antiqua. The highest activity rates of both $\mathrm{O}_{2}{ }^{-}$and $\mathrm{H}_{2} \mathrm{O}_{2}$ per carbon content $\left(\mu \mathrm{g}_{\mathrm{Carbon}^{-1}}\right.$ ) were observed during the exponential growth phase, but the pattern of ROS generation was significantly different between $\mathrm{O}_{2}^{-}$and $\mathrm{H}_{2} \mathrm{O}_{2}$ during cell growth. Two sets of intensive observations (at $3 \mathrm{~h}$ intervals) were conducted for diel phasing of the cell cycle in the exponential and stationary growth phases. In the exponential growth phase, $\mathrm{O}_{2}^{-}$and $\mathrm{H}_{2} \mathrm{O}_{2}$ production rates increased during the light period and decreased during the dark period, in spite of the increase in cell density due to cell division, indicating that the rates were affected by photosynthesis. The patterns of ROS production during the stationary growth phase were similar to those in the exponential phase, although the growth rate had less effect during the stationary than in the exponential phase.
\end{abstract}

KEY WORDS: Cell cycles $\cdot$ Chattonella antiqua $\cdot$ Hydrogen peroxide $\cdot$ NIES culture tank $\cdot$ Reactive oxygen species $\cdot$ Red tide $\cdot$ Superoxide anion

Resale or republication not permitted without written consent of the publisher

\section{INTRODUCTION}

Chattonella antiqua is one of the most harmful red tide flagellates, and causes serious damage to the Japanese fish farming industry. It is particularly harmful to the young yellowtail Seriola quinqueradiata (Shimada et al. 1983, Toyoshima et al. 1985). In recent years, increases in red tides due to Chattonella spp. have been noted worldwide (e.g. Marshall et al. 2002). Because of the enormous economic loss, mass fish mortality induced by Chattonella spp. has become a major social problem, in addition to more typical forms of marine pollution. Although the detailed mechanism for the ichthyotoxicity of Chattonella spp. is unknown, suffocation is generally accepted as the direct cause of death (Endo et al. 1985, Sakai et al. 1986).

A number of studies have reported that Chattonella spp. generate reactive oxygen species (ROS), such as the superoxide anion $\left(\mathrm{O}_{2}^{-}\right)$, hydrogen peroxide $\left(\mathrm{H}_{2} \mathrm{O}_{2}\right)$ and the hydroxyl radical $(\cdot \mathrm{OH})$ (Shimada et al. 1989, 1991, 1993, Oda et al. 1992a,b, 1993, 1994, 1995, 1997, 1998, Tanaka et al. 1992, 1994, Kawano et al. 1996). In 
addition to Chattonella spp., tested strains of the flagellates Heterosigma akashiwo, Fibrocapsa japonica and Olisthodiscus luteus, all of which belong to the class Raphidophyceae, have been reported to generate ROS under normal culture conditions (Yang et al. 1995, Oda et al. 1997, Kim et al. 1999a). Thus, the production of ROS is one of the common characteristics of raphidophyean flagellates.

It is known that ROS are generated in various biological systems, and that their influence is harmful to living organisms (Babior 1978, Johnson et al. 1981, Halliwell \& Gutteridge 1984, Dean 1987, Oda et al. 1989). The generation of ROS is most likely to be controlled by oxidoreductases using $\mathrm{NAD}(\mathrm{P}) \mathrm{H}$ for the reduction of $\mathrm{O}_{2}$ to $\mathrm{O}_{2}{ }^{-}$(Boveris et al. 1972, Thompson et al. 1987). The ability of $\mathrm{NAD}(\mathrm{P}) \mathrm{H}$ oxidases found in plant plasma membranes to generate $\mathrm{O}_{2}{ }^{-}$and $\mathrm{H}_{2} \mathrm{O}_{2}$ has also been shown (Vianello et al. 1990). There is increasing evidence to suggest that $\mathrm{NAD}(\mathrm{P}) \mathrm{H}$ oxidases may be related to some important physiological functions. Interestingly, our recent studies (Kim et al. 2000) have reported that human neutrophil NAD(P)H oxidase also occurs in another species of the Chattonella genus, C. marina. This was demonstrated by Western blotting, using an antibody raised against human neutrophil NAD(P)H oxidase (gp91 phox) (Kim et al. 2000). It was also found that the cell-free supernatant prepared from C. marina, which is thought to contain the glycocalyx, showed NAD(P)H-dependent $\mathrm{O}_{2}^{-}$generation (Kim et al. 2001). The discharged glycocalyx (polysaccharide-containing structure on the cell surface) may be involved in C. marina ROS-mediated severe gill tissue damage, which leads to death of the fish; this occurred through the gill surface (Kim et al. 2001).

Furthermore, previous studies have reported that Chattonella spp. exhibited ROS-mediated toxic effects on the marine bacterium Vibrio alginolyticus (Oda et al. 1992b, Kim et al. 1999b). Recent studies have demonstrated that a toxic response of juvenile rainbow trout Onocorhynchus mykiss to the presence of Heterosigma carterae (synonym of Heterosigma akashiwo), which also produces ROS, can be prevented by superoxide dismutase (SOD) and catalase, which are specific inhibitors of $\mathrm{O}_{2}^{-}$and $\mathrm{H}_{2} \mathrm{O}_{2}$, respectively (Yang et al. 1995). Since ROS are generally considered to be toxic to living organisms, the ROS generated by Chattonella spp. may be responsible for the gill tissue injury, which eventually causes fish death.

Several lines of evidence suggest that ROS are involved in the ichthyotoxicity of Chattonella spp. Ishimatsu et al. (1996) found that a strain of Chattonella producing very low levels of $\mathrm{O}_{2}^{-}$was less toxic to yellowtail than another strain producing higher levels of $\mathrm{O}_{2}{ }^{-}$. One of the aims of the present study was to evaluate the ichthyotoxicity of $C$. antiqua, which is the most notorious species in Japan due to the ROS, and to compare the mechanisms of ROS production between C. antiqua and C. marina (Oda et al. 1995).

The pathways for ROS generation associated with cell cycles in the flagellates remain to be explained. Oda et al. (1995) reported from their flask level experiments that the generation rate of $\mathrm{O}_{2}^{-}$and $\mathrm{H}_{2} \mathrm{O}_{2}$ of Chattonella marina was higher during the exponential growth phase and decreased during the stationary phase. However, little is known about the detailed mechanisms of ROS generation in relation to the L:D cycle and the carbon accumulation by this flagellate during cell growth. Such a comprehensive analysis requires a large volume of algae samples grown under axenic culture conditions without strong shaking or wall-effects. The NIES (National Institute for Environmental Studies) culture tank (Fig. 1) has been used to grow algae in large volumes (about $1 \mathrm{~m}^{3}$ of $\mathrm{f} / 2$ medium) for several weeks under axenic conditions (Kohata \& Watanabe 1986). Samples of $C$. antiqua can be obtained without any effect on the cells left in the tank, and subjected to immediate determination of $\mathrm{O}_{2}{ }^{-}$ and $\mathrm{H}_{2} \mathrm{O}_{2}$ production rates. Therefore, the second aim of this study was to investigate the generation of $\mathrm{O}_{2}{ }^{-}$ and $\mathrm{H}_{2} \mathrm{O}_{2}$ by $C$. antiqua during cell growth, as well as the effect of diel phasing of the cell cycle using the culture tank at NIES.

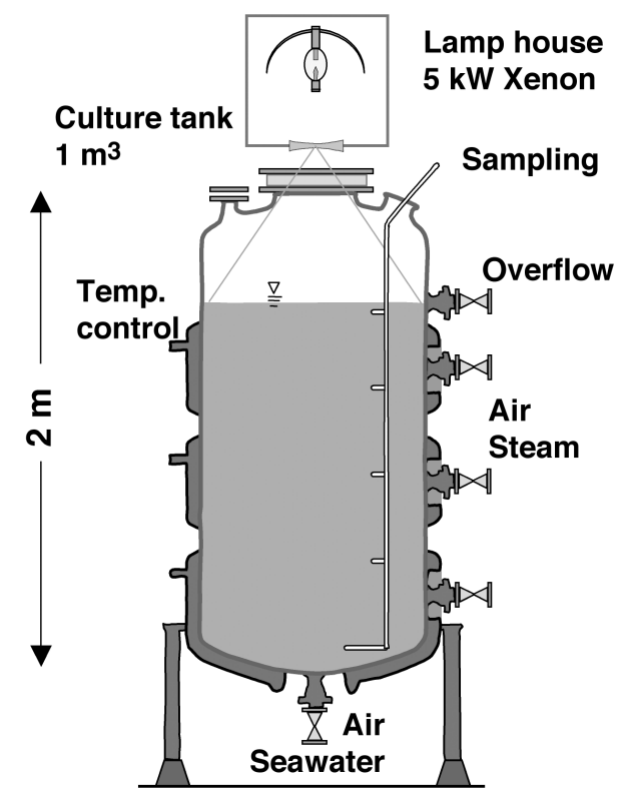

Fig. 1. Drawing of NIES culture tank. Chattonella antiqua cells were cultured in the tank containing $1 \mathrm{~m}^{3}$ of $\mathrm{f} / 2$ medium under axenic conditions. Fully mixed conditions were maintained throughout the culture experiments by introducing sterilized air as fine bubbles from the bottom of the tank. Water temperature was kept constant at $23 \pm 1^{\circ} \mathrm{C}$ 


\section{MATERIALS AND METHODS}

Plankton culture. A strain of Chattonella antiqua (NIES-1) was generously provided by the NIES Microbial Culture Collection. The stock culture was maintained in f/2 medium (Guillard \& Ryther 1962) under $80 \mu \mathrm{mol}$ photons $\mathrm{m}^{-2} \mathrm{~s}^{-1}$ illumination with a cycle of 12:12 h L:D at $23 \pm 1^{\circ} \mathrm{C}$. All cultivation was carried out under sterile conditions.

NIES culture tank. A NIES culture tank $(2 \mathrm{~m}$ high, $1 \mathrm{~m}$ internal diameter, working volume about $1 \mathrm{~m}^{3}$ and airspace about $0.4 \mathrm{~m}^{3}$ ) was used to grow Chattonella antiqua under axenic conditions, as shown in Fig. 1 (Kohata \& Watanabe 1986, 1988). Filters for air and seawater and pipelines between these filters were sterilized by steam $\left(110^{\circ} \mathrm{C}, 0.5 \mathrm{~kg} \mathrm{~cm}^{-2}\right.$ pressure) for $30 \mathrm{~min}$. The tank was filled with $1 \mathrm{~m}^{3}$ of $\mathrm{f} / 2$ medium, which was sterilized through 3 levels of filter (final filter was $0.1 \mu \mathrm{m}$ Millidisk, Nipponpore). Then $1 \mathrm{l}$ of $C$. antiqua pre-culture, in a 21 Erlenmeyer flask containing $1 \mathrm{l}$ of $\mathrm{f} / 2$ medium, prepared as above $\left(8.0 \times 10^{2}\right.$ cells $\mathrm{ml}^{-1}$ in the exponential phase of growth), was inoculated into the tank to give an initial cell concentration of 1 to 2 cells $\mathrm{ml}^{-1}$. Illumination was provided by daylight $5 \mathrm{~kW}$ xenon lamps, at an irradiance level of about $565 \mu \mathrm{mol}$ photons $\mathrm{m}^{-2} \mathrm{~s}^{-1}$ with a cycle of 12:12 h L:D (L: 06:00 to 18:00 h). The temperature was kept at $23 \pm$ $1^{\circ} \mathrm{C}$. Sterilized air in the form of fine bubbles (bubbling rate; $200 \mathrm{ml} \mathrm{min}^{-1}$ ) was introduced from the bottom of the culture tank, providing fully mixed conditions in the tank. Other experimental details have been described elsewhere (Watanabe et al. 1991, Kimura et al. 1999). The cell density was monitored once per day at 13:00 $\mathrm{h}$ at the middle level of the tank. The cell density reached the exponential growth phase several days after inoculation. Detailed measurements were then started, and continued for $24 \mathrm{~h}$ at $3 \mathrm{~h}$ intervals during the exponential (Day 11 to 12) and stationary (Day 15 to 16) growth phases.

Cell count and particulate carbon measurements. Samples were collected through Teflon tubes attached to the middle of the tank. Cell density and mean cell volume were measured using a cell counting system (Coulter Multisizer II). Samples were also examined using a light microscope (OPTIPHOT, Nikon) in order to observe changes in cell shape (Watanabe et al. 1991, Kimura et al. 1999). For particulate carbon measurements, samples of water $(500 \mathrm{ml})$ were filtered (filtration vacuum; $400 \mathrm{~mm} \mathrm{Hg}$ ) through precombusted $\left(450^{\circ} \mathrm{C}\right.$ for $\left.4 \mathrm{~h}\right)$ Whatman GF/C 47 -mm glass-microfibre filters. The filters were rinsed with $0.5 \mathrm{M}$ ammonium formate and stored at $-20^{\circ} \mathrm{C}$ until analysis. After the filters had been dried in a forced-air oven at $80^{\circ} \mathrm{C}$ for $48 \mathrm{~h}$, particulate carbon on the filters was measured with a CHN analyzer (MT-3, Yanaco; Kimura et al. 1999).
Measurement of superoxide anion. Generation of the superoxide anion $\left(\mathrm{O}_{2}^{-}\right)$was measured by the chemiluminescence method using 2-methyl-6( $p$ methoxyphenyl)-3,7-dihydroimidazo[1,2-] pyrazin-3one (MCLA) as a superoxide-specific chemiluminescent probe (Lee et al. 1995, Oda et al. 1998). MCLA was dissolved in distilled water and stored at $-30^{\circ} \mathrm{C}$ until use. After the addition of MCLA to a cell suspension, the chemiluminescence response was recorded immediately with a Luminoskan TL Plus (Thermo Labsystems). As the levels of the $\mathrm{O}_{2}^{-}$generation detected by chemiluminescence responses were significantly high during the first $30 \mathrm{~s}$ of exposure after introducing cells to MCLA, the responses were accumulated for that time (Nakamura et al. 1998). The reaction mixtures typically consisted of $500 \mu \mathrm{l}$ cell suspension, $166 \mu \mathrm{l}$ MCLA solution (final $5 \mu \mathrm{g} \mathrm{ml}^{-1}$ ), and $15 \mu \mathrm{SOD}$

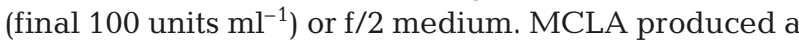
slight chemiluminescence response in $\mathrm{f} / 2$ medium, but a similar level of response was also observed in distilled water under the same experimental conditions. Therefore, the value in $f / 2$ medium alone was subtracted from each value as non-specific background. All chemiluminescence analysis was done at $27^{\circ} \mathrm{C}$.

Measurement of hydrogen peroxide. Detection of hydrogen peroxide $\left(\mathrm{H}_{2} \mathrm{O}_{2}\right)$ in the cell suspension was done using the PHPA ( $p$-hydroxyphenylacetate) assay method at $27^{\circ} \mathrm{C}$ (Hyslop \& Sklar 1984). After addition of PHPA (final $1 \mathrm{mM}$ ) and horseradish peroxidase (final $100 \mathrm{mg} \mathrm{ml}^{-1}$ ) to the cell suspension in $\mathrm{f} / 2$ medium, an increase in fluorescence intensity during the first minute of incubation was measured with a fluorescence spectrophotometer (Shimadzu RF-540) at an excitation wavelength of $317 \mathrm{~nm}$ and an emission wavelength of $400 \mathrm{~nm}$, in the presence or absence of 500 units $\mathrm{ml}^{-1}$ catalase. The catalase-inhibited increase in fluorescence was considered to reflect actual $\mathrm{H}_{2} \mathrm{O}_{2}$. The concentration of $\mathrm{H}_{2} \mathrm{O}_{2}$ was estimated using a standard curve of $\mathrm{H}_{2} \mathrm{O}_{2}$ in cell-free $\mathrm{f} / 2$ medium. The standard solution of $\mathrm{H}_{2} \mathrm{O}_{2}$ in $\mathrm{f} / 2$ medium was prepared from reagent $\mathrm{H}_{2} \mathrm{O}_{2}$ (Santoku Chemical Industries). Under these assay conditions, the increase in fluorescence was proportional to the concentration of $\mathrm{H}_{2} \mathrm{O}_{2}$.

\section{RESULTS}

\section{$\mathrm{O}_{2}{ }^{-}$and $\mathrm{H}_{2} \mathrm{O}_{2}$ production during growth phases}

After inoculation of cells into the tank at an initial density of 1 to 2 cells ml ${ }^{-1}$, growth was measured by counting live cells at $1 \mathrm{~d}$ intervals. The growth curve illustrated in Fig. 2B shows that the exponential phase continued to Day 14 , reaching a cell density of about $1.7 \times 10^{3}$ cells ml ${ }^{-1}$. The $\mathrm{pH}$ values changed from 8.08 


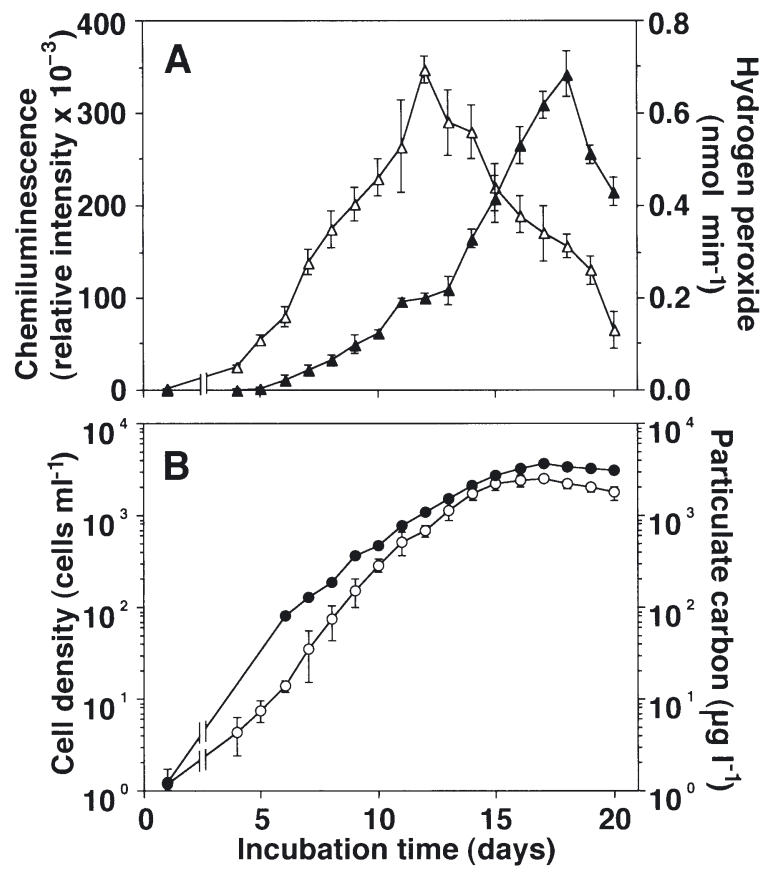

Fig. 2. Chattonella antiqua. Changes of superoxide anion $\left(\mathrm{O}_{2}^{-}\right)$generation and production of hydrogen peroxide $\left(\mathrm{H}_{2} \mathrm{O}_{2}\right)$ during the growth phase. (A) $\mathrm{O}_{2}^{-}$generation detected by chemiluminescence responses $(\Delta)$ and production of $\mathrm{H}_{2} \mathrm{O}_{2}(\mathbf{\Delta})$; (B) cell densities (O) and particulate carbon $(\bullet) . \mathrm{N}=3, \pm \mathrm{SD}$

to 9.06 from the beginning to the end of the experiment in the tank. As shown in Fig. 2B, particulate carbon changed in parallel with that of cell density. The specific growth rate $\mu$ (ln unit of increase $\mathrm{d}^{-1}$ ) was $0.67 \mathrm{~d}^{-1}$ at the beginning of the exponential phase. The specific growth rate was calculated from the following equation:

$$
\mu=\ln \left(N_{2} / N_{1}\right) /\left(d_{2}-d_{1}\right)
$$

where $N_{\mathrm{i}}$ is cell density at the $d_{\mathrm{i}}$ th day (Kohata \& Watanabe 1988). The stationary growth phase started on Day 15 with a cell density of about $2.2 \times 10^{3}$ cells $\mathrm{ml}^{-1}$, and then decreased subsequently.

$\mathrm{O}_{2}{ }^{-}$and $\mathrm{H}_{2} \mathrm{O}_{2}$ production was also measured at $1 \mathrm{~d}$ intervals at the same time of day (13:00 h), to examine the relationship between the $\mathrm{O}_{2}{ }^{-}$and $\mathrm{H}_{2} \mathrm{O}_{2}$ production and the growth phase (Fig. 2A). The highest peak value was observed during the exponential phase with a cell density of about $6.8 \times 10^{2}$ cells m$^{-1}$ (Fig. 2B). After the population had reached the stationary phase, the production of $\mathrm{O}_{2}^{-}$decreased gradually and remained at a low level during this phase. However, as shown in Fig. 2A, the maximal production of $\mathrm{H}_{2} \mathrm{O}_{2}$ was found during the stationary phase rather than the exponential phase. These results indicate that the $\mathrm{O}_{2}^{-}$generation pathway in Chattonella antiqua is different from that of $\mathrm{H}_{2} \mathrm{O}_{2}$.

\section{Activity of $\mathrm{O}_{2}^{-}$and $\mathrm{H}_{2} \mathrm{O}_{2}$ generation per particulate carbon content (GPC)}

In order to investigate the generation of $\mathrm{O}_{2}{ }^{-}$and $\mathrm{H}_{2} \mathrm{O}_{2}$ during the growth phases in relation to cell metabolism, the intensity of the chemiluminescence response and the concentration of $\mathrm{H}_{2} \mathrm{O}_{2}$ were divided by the determined particulate carbon $(\mu \mathrm{g})$ of the cells (Fig. 3). As shown in Fig. 3, higher efficiencies of both calculated $\mathrm{O}_{2}^{-}$and $\mathrm{H}_{2} \mathrm{O}_{2}$ generation rates per particulate carbon content $\left(\mathrm{GPC}_{i} \mu \mathrm{g} \mathrm{carbon}^{-1}\right.$ ) were found from Days 6 to 10 (i.e. during the exponential phase). The GPC of $\mathrm{O}_{2}^{-}$increased only in the exponential growth phase and subsequently decreased in the stationary phase, whereas there was no significant change in the GPC of $\mathrm{H}_{2} \mathrm{O}_{2}$ during the late stationary phase.

\section{Diel changes in ROS generation activity during growth phases}

To ascertain whether or not the activities of $\mathrm{O}_{2}{ }^{-}$and $\mathrm{H}_{2} \mathrm{O}_{2}$ were influential in the light effect, the production rates of $\mathrm{O}_{2}{ }^{-}$and $\mathrm{H}_{2} \mathrm{O}_{2}$ were examined at $3 \mathrm{~h}$ intervals for diel phasing of the cell cycle in the exponential phase, together with measurements of cell density. As shown in Fig. 4A, both $\mathrm{O}_{2}{ }^{-}$and $\mathrm{H}_{2} \mathrm{O}_{2}$ increased during

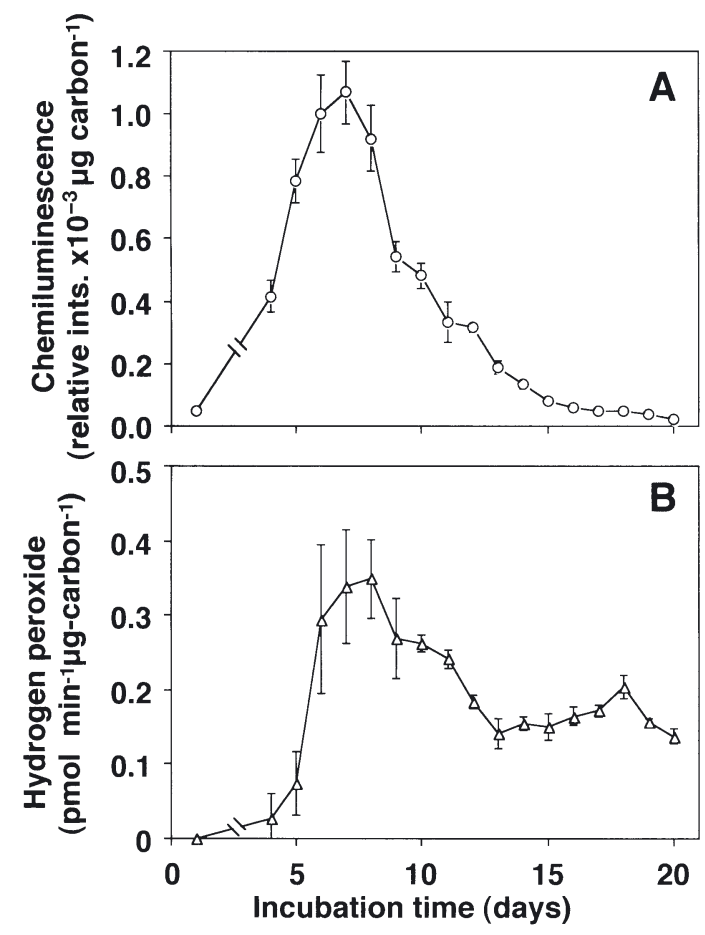

Fig. 3. Chattonella antiqua. Activity of $\mathrm{O}_{2}^{-}$(A) and $\mathrm{H}_{2} \mathrm{O}_{2}$ (B) generation per particulate carbon content (GPC) during cell growth 


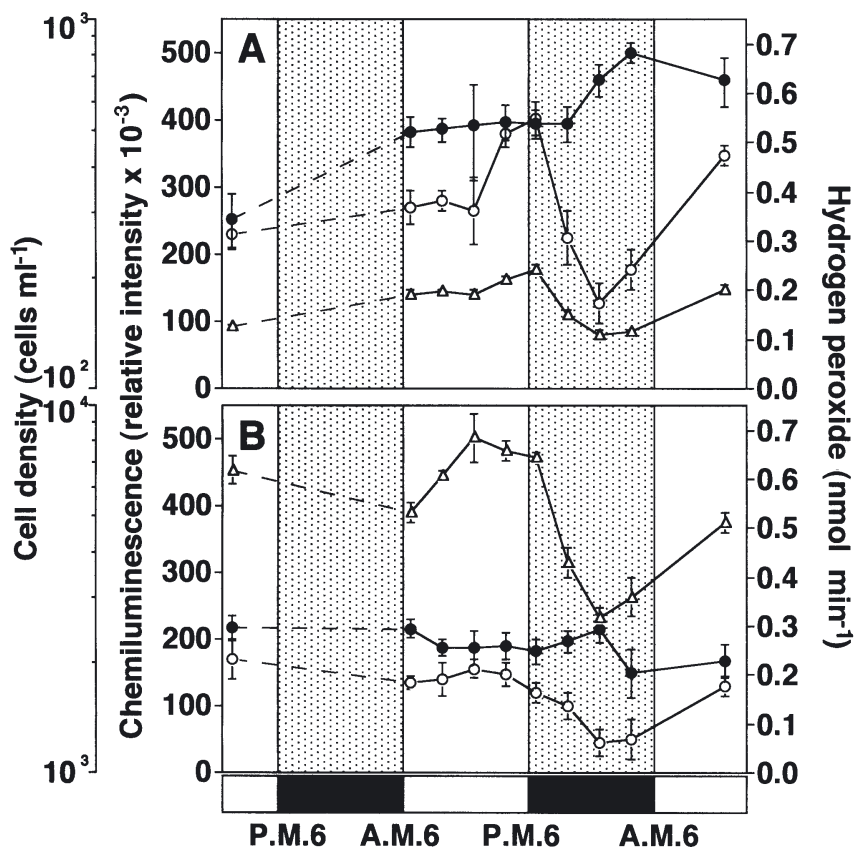

Fig. 4. Chattonella antiqua. Diel changes in activity of $\mathrm{O}_{2}^{-}$and $\mathrm{H}_{2} \mathrm{O}_{2}$ generation during the exponential growth phase (A) and the stationary growth phase (B) in the NIES tank. Cell densities $(\bullet), \mathrm{O}_{2}^{-}$generation $(\mathrm{O}), \mathrm{H}_{2} \mathrm{O}_{2}$ generation $(\Delta)$. Dotted areas denote the dark period of the 12:12 h L:D cycle. $\mathrm{N}=3, \pm \mathrm{SD}$

the light period and decreased during the dark period, with the increase in cell concentration occurring as a result of cell division (from 22:00 to 04:00 h). In the light period, the highest activity of chemiluminescence response by $\mathrm{O}_{2}{ }^{-}$and the production of $\mathrm{H}_{2} \mathrm{O}_{2}$ increased gradually to 4 and 2.5 times, respectively, the minimum levels occurring during the dark period. The generation of $\mathrm{O}_{2}{ }^{-}$and $\mathrm{H}_{2} \mathrm{O}_{2}$ in the stationary phase was also examined (Fig. 4B). Although the total activities of $\mathrm{O}_{2}{ }^{-}$and $\mathrm{H}_{2} \mathrm{O}_{2}$ production in the stationary phase differed from those in the exponential phase (about 0.38 and 2.8 times the values for the exponential phase), the extent of the changes induced in the photosynthetic effect appeared similar to those in the exponential phase. The maximum rate for $\mathrm{O}_{2}^{-}$was 3.4 times the minimum value during the dark period, while the rate for $\mathrm{H}_{2} \mathrm{O}_{2}$ was 2.3 times higher.

\section{Comparison of ROS generation activity during growth phases}

The changes in ROS generation for $\mathrm{O}_{2}^{-}$and $\mathrm{H}_{2} \mathrm{O}_{2}$ production in the exponential and stationary phases were calculated by dividing the total activity by particulate carbon of the cell to obtain GPC values. The com-

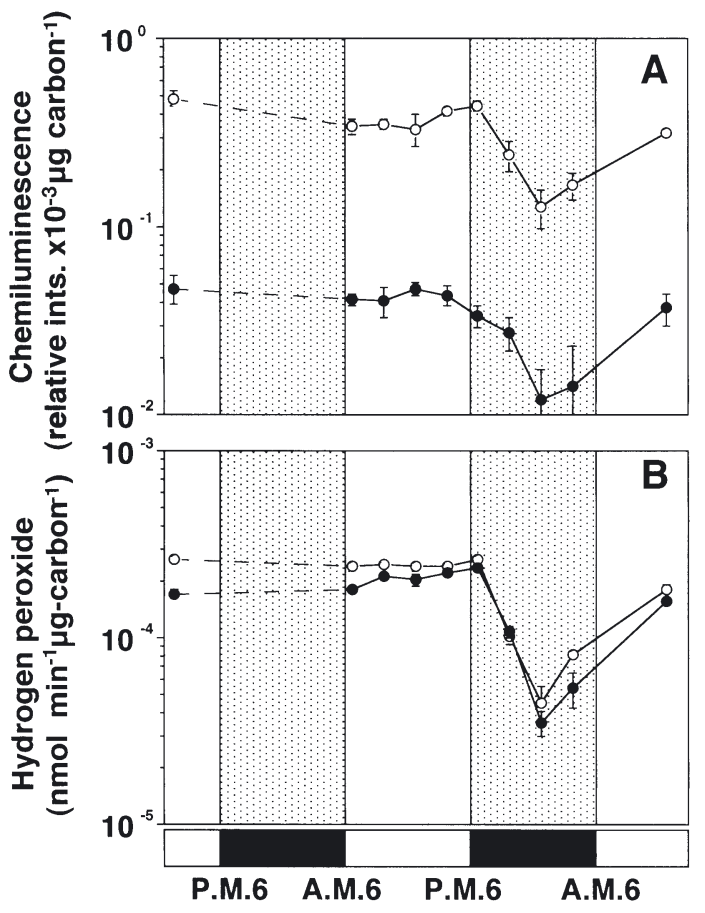

Fig. 5. Chattonella antiqua. Diel change in GPC values for $\mathrm{O}_{2}{ }_{2}^{-}$ (A) and $\mathrm{H}_{2} \mathrm{O}_{2}$ (B) during the exponential (O) and stationary $(\bullet)$ growth phases. Dotted areas denote the dark period of the 12:12 h L:D cycle. $\mathrm{N}=3, \pm \mathrm{SD}$

parisons are shown in Fig. 5. All GPC values for $\mathrm{O}_{2}^{-}$ and $\mathrm{H}_{2} \mathrm{O}_{2}$ increased during the light period and subsequently decreased in the dark period, but in clearly different ways. The GPC of $\mathrm{O}_{2}^{-}$in the exponential phase was greater than in the stationary phase (Fig. 5). In the case of GPC for $\mathrm{H}_{2} \mathrm{O}_{2}$, the values during the stationary growth phase showed no significant difference from those in the exponential phase (Fig. 5).

\section{DISCUSSION}

Previous studies have reported that Chattonella antiqua grows by cell division occurring almost once per day (about $\mu=0.69 \mathrm{~d}^{-1}$ ) under optimum conditions in flask culture (Nakamura \& Watanabe 1983). As shown in Fig. $2 \mathrm{~B}$, the growth rate obtained in the present study (about $\mu=0.67 \mathrm{~d}^{-1}$ ) was nearly the same as that obtained under the optimum condition and indicated that the large volume of the NIES tank could provide good conditions for growth throughout the culture experiment free from any effect due to sampling of the cells. Moreover, the turbulence used for mixing in the tank was so mild that it did not affect cell growth and kept other external conditions constant throughout the experiment (Kohata \& Watanabe 1987). 
Oda et al. (1995) showed that the generation of $\mathrm{O}_{2}{ }^{-}$ and $\mathrm{H}_{2} \mathrm{O}_{2}$ by Chattonella marina was highest during the exponential growing phase, although the culture size and growth conditions were different from those we used here. The present study showed that another raphidophyceae, C. antiqua, also produced ROS. Although the pattern providing the highest generation of $\mathrm{O}_{2}{ }^{-}$was similar to that in C. marina, the timing of the peak of $\mathrm{H}_{2} \mathrm{O}_{2}$ generation was somewhat different (Fig. 2A), the highest $\mathrm{H}_{2} \mathrm{O}_{2}$ production being observed in the stationary phase. Oda et al. (1997) also reported that the amount of hydrogen peroxide in their culture medium increased significantly after disruption of the cells by sonication on a GF/C glass-fiber filter, compared to the hydrogen peroxide level detected in intact cell suspensions. In addition, histological analyses have shown that $C$. antiqua do not have rigid cell walls, but glycocalyx on the cell surface, and make morphological changes under unsuitable culture conditions such as vigorous shaking or exposure to lower temperature (Tanaka et al. 1992). We also monitored rates of $C$. antiqua cells morphologically changed from the spindle to round or rugged shape, which gradually increased during cell growth under a light microscope (by about 30\%, data not shown). Thus, C. antiqua accumulated $\mathrm{H}_{2} \mathrm{O}_{2}$ at high concentrations within the cell, and gradually released a small amount of $\mathrm{H}_{2} \mathrm{O}_{2}$ until the early stationary growth phase (Fig. 2A).

GPC values were calculated from dividing generation data shown in Fig. 2 by particulate carbon content in order to clearly explain the growth metabolisminduced ROS production (Fig. 3). The highest GPC of $\mathrm{O}_{2}{ }^{-}$and $\mathrm{H}_{2} \mathrm{O}_{2}$ were observed in the early exponential phase. Interestingly, the present study shows that the GPC of $\mathrm{H}_{2} \mathrm{O}_{2}$ remained comparable during the stationary phase, although the value in the stationary growth phase was lower than that in the exponential phase (Fig. 3). These results suggest that production of ROS was related to the growth metabolism-induced cell division of Chattonella antiqua. Similar relations have been found for another raphidophycean flagellate such as Heterosigma akashiwo (Asai et al. 1999) and C. marina (Oda et al. 1995). In agreement with these results, previous evidence has also shown in the case of a higher animal cell that the generation of ROS is one of the earliest events involved in positive control of cell growth in response to growth factors under growth-promoting conditions (Murrell et al. 1990, Shibanuma et al. 1990).

Previous studies on higher plants have shown that ROS production may be related to photosynthetic effects. For example, increasing production of ROS species by senescing thylakoids is sensitive to SOD and appears to be mediated through a photochemical reaction involving chlorophyll (McRae \& Thompson
1983). Chlorophyll is known to act as a photosensitizer by transferring excitation energy and can react directly with oxygen to produce ROS species (Rabinowitch \& Fridovich 1983). Therefore, chlorophyll may act as a primary producer of ROS species. Chattonella antiqua, a small golden-brown raphidophycean flagellate, also contains numerous chloroplasts (chlorophylls $a, c$ and fucoxanthin) in the peripheral cytoplasm (Kohata \& Watanabe 1988). In fact, Kohata \& Watanabe (1988) reported that chlorophyll in C. antiqua showed a significant increase during the light period due to photosynthesis and a decrease during the dark period, the increase in cell concentration occurring as a result of cell division. More recently, Marshall et al. (2002) also demonstrated that ROS generated by Chattonella spp. were significantly decreased by the photosynthesis-blocking herbicide DCMU (3-(3,4dichlorophenyl)-1,1-dimethyl-urea). As shown in Fig. 4, $\mathrm{O}_{2}^{-}$and $\mathrm{H}_{2} \mathrm{O}_{2}$ increased during the light period as a result of photosynthesis and decreased during the dark period in their diel phasing of cell cycle. The pattern of increase is consistent with the above reports. Thus, the mechanism of ROS generation in C. antiqua may be affected by photosynthesis, through an activated electron acceptor with highly reactive oxidants similar to that of higher plants.

The absolute values of production rates for $\mathrm{H}_{2} \mathrm{O}_{2}$, the most stable ROS, can be obtained quantitatively during the cell cycle with the PHPA method under normal culture tank conditions. In the present study, the rate of $\mathrm{H}_{2} \mathrm{O}_{2}$ production by Chattonella antiqua was about $0.46 \mathrm{pmol} \mathrm{min}^{-1}$ per single cell. The rate ranged

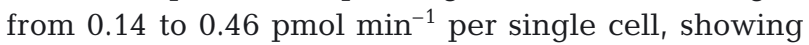
the highest values in the exponential phase (data not shown). Oda et al. (1997) have reported that the rate of $\mathrm{H}_{2} \mathrm{O}_{2}$ production by $C$. antiqua and $C$. marina was 1.0

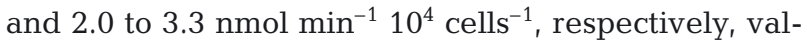
ues that correspond to 0.1 and 0.2 to $0.33 \mathrm{pmol} \mathrm{min}^{-1}$ per single cell, respectively. The rate of $\mathrm{H}_{2} \mathrm{O}_{2}$ production by $C$. antiqua is expected to be higher than that of other raphidophycean flagellates if only cell sizes are considered, because $C$. antiqua has the largest cell (Oda et al. 1997). The rate of $0.46 \mathrm{pmol} \mathrm{min}^{-1}$ per single cell of C. antiqua in the present study is consistent with that for C. marina and considerably higher than the value for $C$. antiqua reported by Oda et al. (1997). In fact, our preliminary experiment has shown that the production rate was decreased significantly in cultures of C. antiqua depleted of nitrogen or phosphorus (authors' unpubl. data). Differences in culture conditions may cause more difficulties in making comparisons.

In order to compare the production rates of ROS in the exponential and stationary growth phases free from the effect of changes in cell size, we calculated GPC values as described before. The GPC for $\mathrm{H}_{2} \mathrm{O}_{2}$ of 
Chattonella antiqua in the stationary phase was similar to that in the exponential phase in terms of level and diel pattern of change (Fig. 5). On the other hand, the GPC of $\mathrm{O}_{2}{ }^{-}$in the stationary phase decreased to a trace level (Fig. 5). The different patterns of decrease shown by $\mathrm{H}_{2} \mathrm{O}_{2}$ and $\mathrm{O}_{2}{ }^{-}$suggest that the $2 \mathrm{ROS}$ are generated by $C$. antiqua, using different mechanisms in its metabolic or enzymatic systems.

Chattonella antiqua is a motile phytoplankton capable of diel vertical migration and nocturnal nutrient uptake. The cells accumulate at the surface during the day for photosynthesis and sink to the nutrient-rich deeper layer during the night. The ecological importance of diel vertical migration for the nutrition and accumulation of flagellates has been examined using the NIES tank (Watanabe et al. 1991, 1995, Kimura et al. 1999). Although the toxicity induced by ROS should be linked with cell migration through the cell cycle and nutrition, the present study was conducted under fully mixed conditions. Observations of ROS formation by C. antiqua under stratified conditions in the tank are in progress, in order to clarify the relationship between the production of ROS and the uptake of nutrients such as $\mathrm{N}$ and $\mathrm{P}$ during cell growth. In a preliminary experiment under the stratified conditions, ROS also showed clear diel change. The production of both $\mathrm{O}_{2}{ }^{-}$and $\mathrm{H}_{2} \mathrm{O}_{2}$ was also increased during the light period due to photosynthesis, and decreased during the dark period, similar to that in the present experiment (data not shown).

In conclusion, our results demonstrate that (1) the generation of ROS for diel phasing of the cell cycle by Chattonella antiqua increases during the light period as a result of photosynthesis and decreases during the dark period, (2) ROS generation rates are closely related to the growth metabolism-induced cell division of C. antiqua, and (3) the pattern of ROS generation was significantly different between $\mathrm{O}_{2}^{-}$and $\mathrm{H}_{2} \mathrm{O}_{2}$ production during cell growth phases.

Acknowledgements. We thank Professor T. Oda (Faculty of Fisheries, Nagasaki University, Japan) for many helpful comments throughout this work.

\section{LITERATURE CITED}

Asai R, Matsukawa R, Ikebukuro K, Karube I (1999) Highly sensitive chemiluminescence flow-injection detection of the red tide phytoplankton Heterosigma carterae. Anal Chim Acta 390:237-244

Babior BM (1978) Oxygen-dependent microbial killing by phagocytes. New Engl J Med 298:721-725

Boveris A, Oshino N, Chance B (1972) The cellular production of hydrogen peroxide. Biochem J 128:617-630

Dean RT (1987) Free radicals, membrane damage and cellmediated cytolysis. Br J Cancer 55:39-45
Endo M, Sakai T, Kuroki A (1985) Histological and histochemical changes in the gills of the yellowtail Seriola quinqueradiata exposed to the Raphidophycean flagellate Chattonella marina. Mar Biol 87:193-197

Guillard RRL, Ryther JH (1962) Studies of marine planktonic diatoms. 1. Cyclotella nana Hustedt and Detonula confervacea (Cleve) Gran. Can J Microbiol 8:229-239

Halliwell B, Gutteridge JMC (1984) Oxygen toxicity, oxygen radicals, transition metals and disease. Biochem J 219: 1-14

Hyslop PA, Sklar LA (1984) A quantitative fluorimetric assay for the determination by polymorphonuclear leukocytes: its use in the simultaneous fluorimetric assay of cellular activation processes. Anal Biochem 141:280-286

Ishimatsu A, Oda T, Yoshida M, Ozaki M (1996) Oxygen radicals are probably involved in the mortality of yellowtail by Chattonella marina. Fish Sci (Tokyo) 62:836-837

Johnson KJ, Fantone JC, Kaplan PA (1981) In vivo damage of rat lungs by oxygen metabolites. J Clin Investig 67: 983-993

Kawano I, Oda T, Ishimatsu A, Muramatsu T (1996) Inhibitory effect of the iron chelator Desferrioxamine (Desferal) on the generation of activated oxygen species by Chattonella marina. Mar Biol 126:765-771

Kim D, Nakamura A, Okamoto T, Komatsu N, Oda T, Ishimatsu A, Muramatsu T (1999a) Toxic potential of the raphidophyte Olisthodiscus luteus: mediation by reactive oxygen species. J Plankton Res 21:1017-1027

Kim D, Oda T, Ishimatsu A, Muramatsu T (1999b) Isolation and characterization of a mutant strain of Chattonella marina with decreased production of superoxide anion. Biosci Biotechnol Biochem 63:1947-1952

Kim D, Nakamura A, Okamoto T, Komatsu N, Oda T, Iida T, Ishimatsu A, Muramatsu T (2000) Mechanism of superoxide anion generation in the toxic red tide phytoplankton Chattonella marina: possible involvement of $\mathrm{NAD}(\mathrm{P}) \mathrm{H}$ oxidase. Biochim Biophys Acta 1524:220-227

Kim D, Okamoto T, Oda T, Tachibana K and 5 others (2001) Possible involvement of the glycocalyx in the ichthyotoxicity of Chattonella marina (Raphidophyceae): immunological approach using antiserum against cell surface structures of the flagellate. Mar Biol 139:625-632

Kimura T, Watanabe M, Kohata K, Sudo R (1999) Phosphate metabolism during diel vertical migration in the raphidophycean alga, Chattonella antiqua. J Appl Phycol 11: 301-311

Kohata K, Watanabe M (1986) Synchronous division and the pattern of diel vertical migration of Heterosigma akashiwo (Hada) Hada (Raphidophyceae) in a laboratory culture tank. J Exp Mar Biol Ecol 100:209-224

Kohata K, Watanabe M (1987) The use of a controlled experimental ecosystem (Microcosm) in studies of mechanism of red tide outbreaks. VII. Growth and its mathematical model of Heterosigma akashiwo, a red tide flagellate, in light-limited synchronous cultures. Re Rept Nat Inst Environ Stud 110:79-88 (in Japanese)

Kohata K, Watanabe M (1988) Diel changes in the composition of photosynthetic pigments and cellular carbon and nitrogen in Chattonella antiqua (Raphidophyceae). J Phycol 24:58-66

Lee TY, Goto N, Niki E, Yokoyama K, Tsuzuki M, Takeuchi T, Karube I (1995) Chemiluminescence detection of red tide phytoplankton Chattonella marina. Anal Biochem 67: 225-228

Marshall J-A, Hovenden M, Oda T, Hallegraeff GM (2002) Photosynthesis does influence superoxide production in the ichthyotoxic alga Chattonella marina (Raphido- 
phyceae). J Plankton Res 24:1231-1236

McRae DG, Thompson JE (1983) Senescence-dependent changes in superoxide anion production by illuminated chloroplasts from bean leaves. Planta 158:185-193

Murrell GAC, Francis MJO, Bromley L (1990) Modulation of fibroblast proliferation by oxygen free-radicals. Biochem J 265:659-665

Nakamura Y, Watanabe MM (1983) Growth characteristics of Chattonella antiqua (Raphidophyceae). Part 1. Effects of temperature, salinity, light intensity and $\mathrm{pH}$ on growth. J Oceanogr Soc Jpn 39:110-114

Nakamura A, Okamoto T, Komatsu N, Ooka S, Oda T, Ishimatsu A, Muramatsu T (1998) Fish mucus stimulates the generation of superoxide anion by Chattonella marina and Heterosigma akashiwo. Fish Sci 64:866-869

Oda T, Wu HC (1993) Cerulenin inhibits the cytotoxicity of ricin, modeccin, Pseudomonas toxin, and diphtheria toxin in brefeldin A-resistant cell lines. J Biol Chem 268: 12596-12602

Oda T, Akaike T, Hamamoto T, Suzuki F, Hirano T, Maeda H (1989) Oxygen radicals in influenza-induced pathogenesis and treatment with pyran polymer conjugated SOD. Science 244:974-976

Oda T, Akaike T, Sato K, Ishimatsu A, Takeshita S, Muramatsu T, Maeda H (1992a) Hydroxyl radical generation by red tide algae. Arch Biochem Biophys 294:38-43

Oda T, Ishimatsu A, Shimada M, Takeshita S, Muramatsu T (1992b) Oxygen-radical-mediated toxic effects of the red tide flagellate Chattonella marina on Vibrio alginolyticus. Mar Biol 112:505-509

Oda T, Ishimatsu A, Takeshita S, Muramatsu T (1994) Hydrogen peroxide production by the red tide flagellate Chattonella marina. Biosci Biotechnol Biochem 58:957-958

Oda T, Moritomi J, Kawano I, Hamaguchi S, Ishimatsu A, Muramatsu T (1995) Catalase- and superoxide dismutaseinduced morphological changes and growth inhibition in the red tide phytoplankton Chattonella marina. Biosci Biotechnol Biochem 59:2044-2048

Oda T, Nakamura A, Shikayama M, Kawano I, Ishimatsu A, Muramatsu T (1997) Generation of reactive oxygen species by raphidophycean phytoplankton. Biosci Biotechnol Biochem 61:1658-1662

Oda T, Nakamura A, Okamoto T, Ishimatsu A, Muramatsu T (1998) Lectin-induced enhancement of superoxide anion production by red tide phytoplankton. Mar Biol 131:383-390

Rabinowitch HD, Fridovich I (1983) Superoxide radicals, superoxide dismutases and oxygen toxicity in plants. Photochem Photobiol 37:679-690

Sakai T, Yamamoto K, Endo M, Kuroki A, Kumanda K, Takeda K, Aramaki T (1986) Changes in the gill carbonic anhydrase activity of fish exposed to Chattonella marina red tide, with special reference to the mortality. Nippon

Editorial responsibility: Edna Granéli, Kalmar, Sweden
Suisan Gakkaishi 52:1351-1354

Shibanuma M, Kuroki T, Nose K (1990) Stimulation by hydrogen-peroxide of DNA-synthesis, competence family geneexpression and phosphorylation of a specific protein in quiescent BALB/3T3 cells. Oncogene 5:1025-1032

Shimada M, Murakami TH, Imahayashi T, Ozaki HS, Toyoshima T, Okaichi T (1983) Effects of sea bloom, Chattonella antiqua, on gill primary lamellae of the young yellowtail, Seriola quinqueradiata. Acta Histochem Cytochem 16:232-244

Shimada M, Shimono R, Murakami TH, Yoshimatsu S, Ono C (1989) Red tide, Chattonella antiqua reduces cytochrome c from horse heart. In: Okaichi T, Anderson DM, Nemoto T (eds) Red tides: biology, environmental science, and toxicology. Elsevier, New York, p 443-446

Shimada M, Nakai N, Goto H, Watanabe M, Watanabe H, Nakanishi M, Yoshimatsu S, Ono C (1991) Free radical production by the red tide alga, Chattonella antiqua. J Histochem 23:362-365

Shimada M, Kawamoto Y, Nakatsuka Y, Watanabe M (1993) Localization of superoxide anion in the red tide alga Chattonella antiqua. J Histochem Cytochem 41:507-511

Tanaka K, Yoshimatsu S, Shimada M (1992) Generation of superoxide anions by Chattonella antiqua: possible causes for fish death by 'Red Tide'. Experientia 48:888-890

Tanaka K, Muto Y, Shimada M (1994) Generation of superoxide anion radicals by the marine phytoplankton organism, Chattonella antiqua. J Plankton Res 16:161-169

Thompson JE, Legge RL, Barber RF (1987) The role of free radicals in senescence and wounding. New Phytol 105: $317-344$

Toyoshima T, Ozaki HS, Shimada M, Okaichi T, Murakami TH (1985) Ultrastructural alterations on chloride cells of the yellowtail Seriola quinqueradiata, following exposure to the red tide species Chattonella antiqua. Mar Biol 88: 101-108

Vianello A, Zancani M, Macr F (1990) Hydrogen peroxide formation and iron ion oxidoreduction linked to $\mathrm{NADH}$ oxidation in radish plasmalemma vesicles. Biochim Biophys Acta 1023:319-324

Watanabe M, Kohata K, Kimura T (1991) Diel vertical migration and nocturnal uptake of nutrients by Chattonella antiqua under stable stratification. Limnol Oceanogr 36: 593-602

Watanabe M, Kohata K, Kimura T, Takamatsu T, Yamaguchi S, Ioriya T (1995) Generation of Chattonella antiqua bloom by imposing a shallow nutricline in a mesocosm. Limnol Oceanogr 40:1447-1460

Yang CZ, Albright LJ, Yousif AN (1995) Oxygen-radicalmediated effects of the toxic phytoplankter Heterosigma carterae on juvenile rainbow trout Oncorhynchus mykiss. Dis Aquat Org 23:101-108

Submitted: July 1, 2003; Accepted: January 27, 2004

Proofs received from author(s): March 1, 2004 